\title{
Effects of Polydispyrenia simulii (Microspora; Duboscqiidae) on Development of the Gonads of Simulium pertinax (Diptera; Simuliidae)
}

\author{
A Castello Branco Jr \\ Departamento de Ciências Farmacêuticas, Faculdade de Ciências Farmacêuticas, Nutricionais e do Esporte, \\ Universidade de Marília, Av. Higino Muzzi Filho 1001, 17525-902 Marília, SP, Brasil
}

The effects of the infection caused by the microsporidium Polydispyrenia simulii in gonads of the simuliid Simulium pertinax were evaluated. This blackfly species is the main target of control programmes in southeastern Brazil. Infected and noninfected blackflies were reared from larval stage to adults using a laboratory rearing system. There was no significant difference between the oogenic development and dimensions of ovarian follicles of healthy females compared to those reared from infected larvae. Otherwise, there was a significant difference between the fecundity of healthy females and those reared from infected larvae. In males, there was an evident reduction of motility of spermatozoids of males reared from infected larvae. The results obtained suggest that the microsporidium $\mathrm{P}$. simulii have an important effect on the natural population dynamics of $\mathrm{S}$. pertinax.

Key words: microspora - gonad - Simulium pertinax - Polydispyrenia simulii

Microsporidial infections of insects are often chronic and nonlethal in nature. Consequently, epizootics of these pathogens do not usually result in dramatic suppression of host populations. Rather, such pathogens exert sublethal effects on their hosts such as reduced fecundity, shortened longevity and a general loss of vigor.

Medically important insects and agricultural pests have been investigated for a long time with regard to sublethal effects caused by microsporidiosis (Gaugler \& Brooks 1975, Andreadis \& Hall 1979, Andreadis 1983, 1985, Sweeney et al. 1989, Lockwood \& Debrey 1990, Castello Branco Jr 1998). Blackflies represent an important family among the medically important insects due to their role as vectors of human and animal helminthiasis and because the nuisance caused by their biting habit (Crosskey 1990). Simulium pertinax Kollar is the most antropophilic species occurring in southeastern Brazil and is the main target of government and other control programmes in these areas.

Although microsporidia are considered the most common and worldwide blackfly pathogen, their ecology and epizootiology are poorly known in this host group. The aim of this work is to evalu-

Fax: +55-14-422.3118. E-mail: abranco@mii.zaz.com.br Received 15 September 1998

Accepted 24 February 1999 ate the effects of the infection caused by the microsporidium Polydispyrenia simulii in the gonads of both sexes of the blackfly $S$. pertinax reared from heavily infected larvae.

\section{MATERIALS AND METHODS}

Larvae of $S$. pertinax were collected from their natural breeding sites and kept in a laboratory rearing system adapted from Raybould and Grunewald (1975) (Fig.). Separate rearing systems were stocked with blackfly larvae infected and not-infected with $P$. simulii. Adults of both sexes originating from healthy and infected larvae were obtained from the system and then transfered to glass holding chambers of $0.29 \mathrm{~m}^{3}$. The rearing system and the chambers were maintained at room temperature without photoperiod control. The adults originated from healthy and infected larvae were kept separate.

Human bait (nude forearm) was offered to the female flies twice a day (40 min each one). Filter paper bands soaked in $20 \%$ sucrose solution were also provided for the adults to feed. After blood feeding, each $S$. pertinax female was maintained in glass vials of $40 \mathrm{ml}$ containing filter paper bands soaked with sucrose solution.

S. pertinax males and females were dissected in $0.85 \%$ saline solution at regular intervals. Females were dissected after the seventh day from the first blood meal while males were dissected after the fourth day from the adult fly emergence. The testes and ovaries were examined under the microscope (100x up to $1,000 \mathrm{x})$. The motility of 
spermatozoids was measured in $S$. pertinax males as the time interval between the beginning of the observation up to the moment that spermatozoids showed no more movements. In females, the stage of ovarian development was determined and the developing follicles and eggs were measured and counted. A volume estimation of follicles was calculated by the spheroid prolade formula $[\mathrm{V}=0.5236$ . W ${ }^{2}$. L; V: volume, W: width, L: length] (King \& Vanoucek 1960). Follicle development was characterized using the modification of Christopher's concept for mosquitoes (Charlwood et al. 1980).

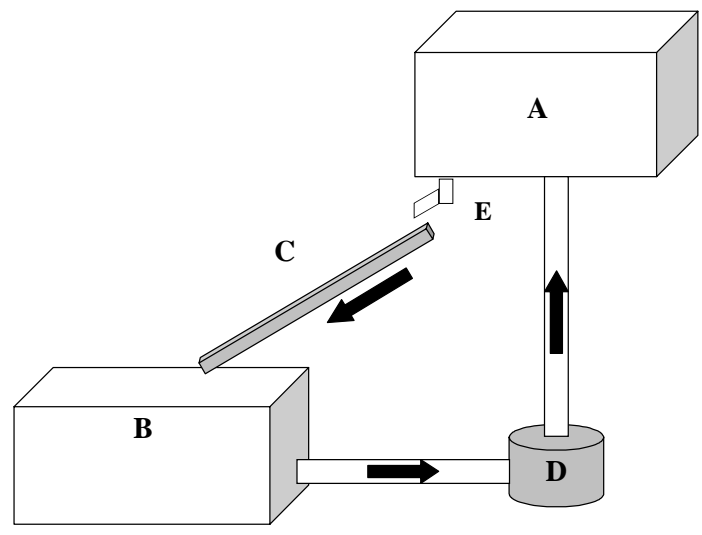

Blackfly rearing system. A: higher water reservoir; B: lower water reservoir; C: wood ramps for blackfly colonization; D: electric water pump; E: tap system. Arrows indicate the water flow.

\section{RESULTS}

Each ovariole of the two polytrophic-meroistic ovaries of $S$. pertinax contains a terminal germarium and a series of follicles which are attached proximally to the oviduct into which a completed egg is shed at the end of each oogenic cycle. Five distinct stages of follicular development were evident after ovary dissection. They are similar to those described for mosquitoes and other blackflies species. Stage 1 is initially caracterized by the presence of two to eight cells that later differentiate in the ovum and the nurse cells. The yolk deposition begins at stage 2 and eventually the yolk occupies up to about one-third of the follicle. The initial deposition of yolk granules is spread inside the follicle. Posteriorly, it is aggregated around the oocyte nucleus. At stage 3, the yolk deposition continues and yolk then occupies about one half to two-thirds of the follicle. At stage 4, the yolk occupies about $70 \%$ to $90 \%$ of follicle volume, and the nurse cells occupy the distal portion of the follicle. Stage 5 is characterized by completion of yolk deposition and membrane formation. At this stage the next follicle is at stage 1 .
Table I shows the follicles dimensions of healthy $S$. pertinax females. An evident increase in dimension is noted in all developmental stages. The mean number of eggs in healthy females was 423.5 ranging from 345 to 502 eggs. The mean number of developing follicles was 193.25 per ovary ranging from 117 to 265 follicles per ovary.

Table II shows the follicles dimensions (stage 1) of healthy females and those originating from heavily infected larvae. There was no significant difference in size of follicles, nor was there any difference in the sequence of oogenic cycles (stage 1 up to stage 5) between healthy females and those originating from infected larvae.

There was a significant reduction of $31.2 \%$ in the fecundity of females originating from infected larvae (Table III).

Spermatozoids of healthy $S$. pertinax males $(n=20)$ showed a mean movement time of $10 \mathrm{~min}$ under microscope observation. Otherwise the spermatozoids of males originated from infected larvae $(n=10)$ moved for only 2 or 3 min (Table IV).

\section{DISCUSSION}

The size of $S$. pertinax eggs (Table I) were similar to those reported for other simullids (Crosskey 1990, Pegoraro 1993). But the number of eggs in $S$. pertinax females differed from the number reported by Pegoraro (1993). We believe that Pegoraro's data on S. pertinax fecundity may have been underestimated, since he studied females of unknown age collected from field. In the present work, we used females reared in the laboratory, all of the same age. Thus, the present results should demonstrate the real reproductive potential of nulliparous $S$. pertinax females.

The comparison between the follicle size of healthy females and those originating from infected larvae (Table II) was possible only for stage 1 due to the low number of adults obtained. A higher standard deviation was obtained for the follicles of females originating from infected larvae suggesting a higher phenotipic heterogeneity.

The site of $P$. simulii infection is the larval fat body (Castello Branco Jr 1994). P. simulii spores are eliminated from the host during the pupal stage of the host by means of a histolytic process. In this way adults originating from infected larvae are free of infection (Castello Branco Jr 1994). Therefore the cause of such higher heterogeneity of follicles size could due to a reduction of energetic reserves in the immature stages due to microsporidian infection.

The reduction in fecundity could also be due to compromised energy reserves in immature stages due to the infection. This reduction of fecundity due to microsporidiosis has been reported in lepi- 
TABLE I

Mean dimensions of follicles at different stages of development in healthy Simulium pertinax females

\begin{tabular}{|c|c|c|c|c|c|c|c|}
\hline \multirow[t]{2}{*}{ Stage } & \multirow[t]{2}{*}{$\mathrm{n}$} & \multicolumn{2}{|c|}{ Width $(\mu \mathrm{m})$} & \multicolumn{2}{|c|}{ Length $(\mu \mathrm{m})$} & \multicolumn{2}{|c|}{ Volume $\left(\mu \mathrm{m}^{3}\right)$} \\
\hline & & $\mathrm{x}$ & $\mathrm{s}$ & $\mathrm{x}$ & $\mathrm{s}$ & $\mathrm{x}$ & $\mathrm{s}$ \\
\hline 1 & 35 & 46.6 & 0.004 & 56.8 & 0.003 & $6.5 \times 10^{3}$ & 0.003 \\
\hline 2 & 23 & 70.7 & 0.010 & 85.3 & 0.013 & $22.3 \times 10^{4}$ & 0.010 \\
\hline 3 & 20 & 79.3 & 0.010 & 105.0 & 0.012 & $35.6 \times 10^{4}$ & 0.011 \\
\hline 4 & 33 & 168.0 & 0.016 & 263.9 & 0.017 & $39.0 \times 10^{5}$ & 0.016 \\
\hline 5 & 10 & 174.1 & 0.017 & 276.2 & 0.020 & $43.8 \times 10^{5}$ & 0.019 \\
\hline
\end{tabular}

$\mathrm{n}$ : number of measurements; $\mathrm{x}$ : mean; s: standard deviation.

TABLE II

Mean dimensions of follicles (stage 1) of Simulium pertinax females originating from Polydispyrenia simulii infected larvae and from healthy ones

\begin{tabular}{|c|c|c|c|c|c|}
\hline \multirow[t]{2}{*}{ Females } & \multirow[t]{2}{*}{$\mathrm{N}(\mathrm{n})$} & \multicolumn{2}{|c|}{ Width $(\mu \mathrm{m})$} & \multicolumn{2}{|c|}{ Length $(\mu \mathrm{m})$} \\
\hline & & $\mathrm{x}$ & $\mathrm{s}$ & $\mathrm{x}$ & $\mathrm{S}$ \\
\hline $\begin{array}{l}\text { Healthy } \\
\text { Infected }\end{array}$ & 35 (197) & $46.6^{\mathrm{a}}$ & 0.004 & $56.8^{\mathrm{b}}$ & $\begin{array}{l}0.003 \\
4150\end{array}$ \\
\hline
\end{tabular}

$\mathrm{N}$ : number of individuals (flies); (n): total number of follicles examined; $\mathrm{x}$ : mean; s: standard deviation; means followed by a common letter are not significantly different at the $p<0.05$ level.

TABLE III

Mean number of follicles per ovary of Simulium pertinax females originating from Polydispyrenia simulii infected larvae and from healthy ones

\begin{tabular}{ccc}
\hline \multicolumn{2}{c}{ Females } \\
\cline { 2 - 3 } & Healthy & Infected \\
\hline $\mathrm{n}$ & 30 & 7 \\
$\mathrm{x}$ & $262.3^{\mathrm{a}}$ & $180.4^{\mathrm{b}}$ \\
$\mathrm{s}$ & 40.9 & 80.1 \\
\hline
\end{tabular}

$\mathrm{n}$ : number of individuals (flies); $\mathrm{x}$ : mean; s: standard deviation; means followed by a common letter are not significantly different at the $p<0.05$ level.

\section{TABLE IV}

Mean time motility (minutes) of spermatozoids of Simulium pertinax males originating from Polydispyrenia simulii infected larvae and from healthy ones

\begin{tabular}{lcc}
\hline & \multicolumn{2}{c}{ Males } \\
\cline { 2 - 3 } & Healthy & Infected \\
\hline $\mathrm{n}$ & 20 & 10 \\
$\mathrm{X}$ & $9.85^{\mathrm{a}}$ & $2.0^{\mathrm{b}}$ \\
$\mathrm{S}$ & $0.98^{\mathrm{n}}$ & 1.05 \\
\hline
\end{tabular}

$\mathrm{n}$ : number of individuals (flies); $\mathrm{x}$ : mean; s: standard deviation; means followed by a common letter are not significantly different at the $p<0.05$ level. dopteran, orthopteran, coleopteran and even dipterous hosts (Castello Branco Jr 1998). A drastic reduction of 77\% was reported in Nosema whitei infection in Tribolium castaneum (Armstrong \& Bass 1986). Even in lepidopteran parasites such as Trichogramma nubilale there was a fecundity reduction when the hosts were infected with microsporidia (Sajap \& Lewis 1988). On the other hand, there are reports that microsporidiosis caused by Amblyospora spp. in some species of culicidae showed no evidence of reduction of fecundity (Andreadis \& Hall 1979, Andreadis 1983, 1985, Sweeney et al. 1989).

The reduction of motility of spermatozoids of S. pertinax males originating from infected larvae may also be due to a reduction in energy reserves in the larval and pupal stages. Once spermatogenesis initiates during the last larval or pupal stages (Dumser 1980), it is possible that the microsporidian infection could interfere with the formation of the mitochondrial derivatives of sperm tail, causing the reduction of the movement time. Further studies are necessary to elucidate this process.

During the dissections no microsporidian spores were detected in S. pertinax ovaries and testes of females and males originating from heavily infected larvae.

$P$. simulii microsporidiosis has been studied in blackflies for a long time by the author. The results obtained in the present work and others 
(Castello Branco Jr 1991, 1994, Castello Branco Jr \& Andrade 1993) confirm that the maintenance of this microsporidiosis should in fact be due to only horizontal transmission. Thus, vertical transmission does not occur in this case. The results also suggest that the effects of fecundity reduction on population dynamics of $S$. pertinax flies could be increased under natural conditions if we associate the reduction of the follicle number in females with the reduction of spermatozoid motility. In this way, we believe that $P$. simulii could be an important regulator factor of natural population dynamics of S. pertinax.

\section{ACKNOWLEDGEMENTS}

To Dr Arício X Linhares (Department of Parasitology, Unicamp) and Dr Mohamed EM Habib (Departament of Zoology, Unicamp) for orientation.

\section{REFERENCES}

Andreadis TG 1983. Life cycle and epizootiology of Amblyospora sp. (Microspora: Amblyosporidae) in the mosquito, Aedes cantator. J Protozool 30: 509518.

Andreadis TG 1985. Life cycle, epizootiology and horizontal transmission of Amblyospora (Microspora: Amblyosporidae) in a univoltine mosquito, Aedes stimulans. J Invertebr Pathol 46: 31-46.

Andreadis TG, Hall DW 1979. Significance of transovarial infections of Amblyospora sp. (Microspora: Thelohanidae) in relation to parasite maintenance in the mosquito Culex salinarius. $J$ Invertebr Pathol 34: 152-157.

Armstrong E, Bass LK 1986. Effects of infection by Nosema whitei on the mating frequency and fecundity of Tribolium castaneum. J Invertebr Pathol 47: 310-316.

Castello Branco Jr A 1991. Estudos Ecológicos e Patológicos da Infecção por Polydispyrenia simulii (Microspora; Pleistophoridae) em uma Comunidade de Simulídeos, MSc Thesis, Unicamp, Campinas, 83 pp.

Castello Branco Jr A 1994. Patologia e Epizootiologia de Simulium pertinax (Diptera; Simuliidae) Infectado por Polydispyrenia simulii (Microspora; Dubosqiidae) e Gastromermis viridis cf. (Nematoda;
Mermithidae), PhD Thesis, Unicamp, Campinas, $120 \mathrm{pp}$.

Castello Branco Jr A 1998. Protozoários entomopatogênicos, p. 571-603. In SB Alves, Controle Microbiano de Insetos, Fealq, Piracicaba, São Paulo.

Castello Branco Jr A, Andrade CFS 1993. Studies on Polydispyrenia simulii (Microspora; Pleistophoridae) in Simulium pertinax (Diptera; Simuliidae) in Brazil. Mem Inst Oswaldo Cruz 88: 167.

Charlwood JD, Rafael JA, Wilkes TJ 1980. Métodos de determinação da idade fisiológica em Diptera de importância médica. Uma revisão com especial referência aos vetores de doenças na América do Sul. Acta Amazonica 10: 311-333.

Crosskey RW 1990. The Natural History of Blackflies, John Wiley \& Sons, NY, 711 pp.

Dumser JB 1980. The regulation of spermatogenesis in insects. Annu Rev Entomol 25: 341-369.

Gaugler RR, Brooks WM 1975. Sublethal effects of infection by Nosema heliothidis in the corn earworm, Heliothis zea. J Invertebr Pathol 26: 57-63.

King RC, Vanoucek EG 1960. Oogenesis in adult Drosophila melanogaster. X. Studies on the behaviour of the follicle cells. Growth 24: 333-338.

Lockwood JA, Debrey LD 1990. Direct and indirect effects of a large-scale application of Nosema locustae (Microsporida: Nosematidae) on rangeland grasshoppers (Orthoptera: Acrididae). J Econ Entomol 83: 377-383.

Pegoraro RA 1993. Ciclo biológico de Simulium (Chirostilbia) pertinax Kollar, 1832 (Diptera: Simuliidae). An Soc Ent Brasil 22: 29-38.

Raybould JN, Grunewald J 1975. Present progress towards the laboratory colonization of African Simuliidae (Diptera). Tropenmed Parasitol 27: 155168.

Sajap AS, Lewis LC 1988. Effects of the microsporidian Nosema pyrausta (Microspora: Nosematidae) on the egg parasitoid, Trichogramma nubilale (Hymenoptera: Trichogrammatidae). J Invertebr Pathol 52: 294-300.

Sweeney AW, Doggett SL, Gullick G 1989. Laboratory experiments on infection rates of Amblyospora dyxenoides (Microsporida: Amblyosporidae) in the mosquito Culex annulirostris. J Invertebr Pathol 53: 85-92. 